\title{
Individual Customers' Access to Credits at Commercial Banks in Viet Nam: The Case of Tra Vinh Province*
}

\author{
Ha Hong NGUYEN ${ }^{1}$
}

Received: June 19, 2020 Revised: June 28, 2020 Accepted: August 10, 2020

\begin{abstract}
The study seeks to explore the factors affecting the access to credits by individual customers at commercial banks in Tra Vinh province, Vietnam. Based on these results, the author proposes solutions to further improve the ability to serve individual customers at commercial banks in the province in the future. The study was conducted with a method of collecting primary data of 300 individual customers including 150 people with access to credits and 150 people without accessing to credits at six commercial banks in Tra Vinh Province, Viet Nam Bank of Agriculture and Rural Development, Bank for Foreign Trade Commercial Bank, Bank for Investment and Development of Vietnam, Asia Commercial Bank in Tra Vinh, Sai Gon Commercial Joint Stock Bank, and Bank of East Asia. The author has used binary regression methods, and the study found that seven factors affecting the ability of individual customers to access capital, namely, career, qualifications, collaterals, incomes, documents, loan and business plans, and experience. In particular, occupation, experience, and documents are the most influential factors. From the above results, the author proposes policy implications to improve individual customers' access to credits at commercial banks in Tra Vinh province in the near future.
\end{abstract}

Keywords: Credits, Individual Customers, Binary Regression, Commercial Banks

JEL Classification Code: D14, E24, G21, Q14

\section{Introduction}

Most commercial banks have always participated effectively in individual credit activities (Nguyen, 2019). Consumer loans are growing rapidly, followed by home loans, staff loans, and family business loans. In order to meet these needs, Agribank staff are increasingly concerned

\footnotetext{
*Acknowledgements:

The author sincerely thanks the support and assistance of the survey team of Faculty of Economics, Tra Vinh University; State Bank of Viet Nam, Tra Vinh Branch and 300 individual customers at six commercial banks in Tra Vinh Province have enthusiastically helped, provided survey data and information. The author sincerely thanks the enthusiastic support of these research groups.

${ }^{1}$ First Author and Corresponding Author. Associate Professor, Vice Dean of School Economics and Law, Tra Vinh University, Viet Nam [Postal Address: 126 Nguyen Thien Thanh Street, Ward 5, Tra Vinh City, Tra Vinh Province, 940000, Viet Nam]

Email: honghaicbtv@yahoo.com.vn; hongha@tvu.edu.vn

(c) Copyright: The Author(s)

This is an Open Access article distributed under the terms of the Creative Commons Attribution Non-Commercial License (https://creativecommons.org/licenses/by-nc/4.0/) which permits unrestricted non-commercial use, distribution, and reproduction in any medium, provided the unrestricted non-commercial use,
original work is properly cited.
}

about individual customers, adjusting policies, and services accordingly to create new, diversified and attractive services to help individual customers, improving the efficiency of distributing loans under the retail models. In the past, corporate loans can be highly risky, leaving large non-performing loans due to inefficient businesses, and personal credits seem to be more effective (State Bank Tra Vinh Branch, 2018). It can be stated that the credit sector is mainly lending to individual customers, which accounts for over $90 \%$ of the total outstanding loans of the branch. Profits generated from individual customers account for over $80 \%$ of total profits (Tran, 2020). However, the commercial banking system still has much potential for lending to individual customers (Le, 2019).

In reality, most banks in Vietnam may not fully exploit the potentials of individual credits. Individual loans are often for people who have stable incomes and feasible business plans, so the risks cannot be as high as business loans. The barriers could be the bank's credit limits and individuals who have a need for credits, but are not eligible to access credits. Official credit demands cannot only be for consumption, but also for production investment. Expanding personal credits also contributes to improving people's lives and social 
development (Van, 2020). Individual credit activities in Tra Vinh are still potential important, but access to credits is challenging for local people (Le, 2019).

\section{Literature Review}

Hawley et al. (1991) analyzed the financial survey data of credit institutions of 3,665 households in the United States in 1983 by using a Probit regression model, identifying several factors: race, age, gender and marital status of the household heads, incomes and expenditures of the households in which the heads of households are male, older, with children and family having high incomes, but low spendings, and white household heads affecting the access to consumers' credits had easier access to credits than black heads. Chien et al. (2001), with a survey of 4,305 households on finance in 1998 in the United States, using the Tobit regression analysis, showed many factors affecting households' credit consumption at the credit institutions. The heads of the households with higher educational levels, family and professional skills, as well as a clear attitude towards debt services would have a higher level of credits. Households with more people and less incomes were also more likely to be able to borrow money.

Kim and DeVaney (2001) conducted a finance survey data of 3,376 households using credit cards (consumers' credits) in the United States in 1998 and Heckman's two-step regression analysis identified many weaknesses. The factors affecting the ability to use credit cards include the age of the household heads, which could have a positive influence, educational attainment of the household heads, incomes, liquid assets, real-estate, interest rates and terms. The loan had the opposite effects. Factors that positively influence the amount of credits are education levels, income level and real-estate value. Khandler (2003) pointed out the influencing factors: age of household heads, educational levels, competitive characteristics of production, and business products. For households, education and ownership of land could be the key to obtaining a loan.

Nuryartono et al. (2005), in a study on formal credit access by rural households in Indonesia, using binary Probit regression analysis, concluded that most of the surveyed farmers were credit-limited. The main effects of strong factors were farm size (number of household members) having a positive impact, while educational levels of the household heads and household incomes were negatively affected. Zhu and De'Armond (2005) surveyed the consumption expenditure of 7,579 households in the United States in 2001, using logit regression analysis, concluded that the factors such as race, marital status, employment status and education of the household heads, income, allowance and housing of the household, had a statistically significant effect on households' access to credits. Educational attainment of the household heads, income and subsidies had a positive impact, and single and unemployed household heads adversely affected the access to credits.

Nguyen and Pham (2010) analyzed the access to formal credits of farmers in suburban Hanoi with two-step Heckman model to identify factors affecting their access to credits. The conclusion was that the age, social status of the household heads, informal credits of the households, and formal loan documents had a positive impact on the ability of the households to access formal credit. Educational levels of the household heads, land area, average income, collaterals, and loan purposes positively impacted on the amount of official household loans. Truong and Tran (2010) studied the ability of farmers to access formal credit in Kien Giang Province and used the Probit model to determine the influencing factor. Farm access to credit is positively correlated with the age, educational levels of the household heads, the number of members, and total assets of the households, and it is inversely correlated with the land area and household heads' incomes.

Le and Pham (2011) studied the determinants of formal credit loans by Hau Giang farmers via Tobit model and concluded the amount of official credit loans is affected by educational attainment, occupation of the household heads, household heads' incomes, distance to district or town market, number of credit institutions, collaterals, number of loans, and so on. These factors would be barriers to poor households with little education, little land, little relationships and low incomes, living in the remote areas. Nguyen and Nguyen (2011) reported that the main factors affecting household heads' ability to access individual credits including household heads' education, household economic conditions, and gender, procedure of lending interest rate, time of loan and amount of loan at individual credit institutions. The enthusiastic attitudes of credit officers can also be an important factor influencing household heads' borrowing decisions.

Tran and Thai (2013) studied the factors affecting household heads' borrowings in commercial banks in Can Tho City using the Probit model to identify the factors that affected household heads' access to credits in commercial banks, and they used the Tobit regression model to identify factors affecting the amount of credit capital for the households. Educational attainment of the household heads, a certificate of land as collateral, the area of land under the use right, and household heads' incomes affected the access to consumers' credits at commercial banks. The amount of consumers' credit capital of a households was affected by the education of the household heads, the land area under the use right, and the household heads' incomes.

Previous studies mainly analyzed the access to credits by farmers and poor households. There is little research on the ability of individual customers to access credits at Agribank 
in Tra Vinh Province, which is the reason for the author choosing this topic.

\section{Research Methodology}

Barslund and Tarp (2008) proposed econometric models to clarify the factors affecting access to credits. Models with dependent variables are used to estimate credit access functions. The dependent variable is a qualitative variable (dummy), which takes value 1 if the borrower has access to credit, and 0 if the borrower does not have access to credit. The model uses a standardized function, thereby determining the probabilities of the factors affecting borrowers' access to credit according to the regression model of the form:

$$
\begin{aligned}
P & =\left(Y=1 / \mathrm{x}_{2} \ldots \mathrm{x}_{k}\right)=p \\
& =F\left(\beta_{1}+\beta_{2} \mathrm{x}_{2}+\beta_{3} \mathrm{x}_{3}+\beta_{4} \mathrm{x}_{4} \ldots+\beta_{k} \mathrm{x}_{k}\right.
\end{aligned}
$$

Independent variables consist of:

- The group of borrower variables relates to personal identities such as age, gender, education levels and so on (see Table 1).

- The variable of borrower's resources such as total asset value, prestige is a resource that is easy to convert value, so credit institutions also base on lending decision, valid papers related to real estate assets.

- The research model has the following form:

$$
\begin{aligned}
\operatorname{Ln}(\mathrm{Pi} / \mathrm{l}-\mathrm{Pi})= & B_{0}+B_{1 \text { Age }}+B_{2 \text { Gender }}+B_{3 \text { Assets }}+B_{4 \text { Incomes }} \\
& +B_{\text {5Documents }}+B_{6 \text { Educational levels }}+B_{\text {7Jobs }} \\
& +B_{\text {8Planning }}+B_{\text {9Experience }}+u_{i}
\end{aligned}
$$

\section{Dependent variable:}

\begin{tabular}{|c|c|c|c|c|}
\hline Variables & Interpretations & Units & $\begin{array}{l}\text { Expecting } \\
\text { marks }\end{array}$ & $\begin{array}{l}\text { Sources that are based to select } \\
\text { variables }\end{array}$ \\
\hline Age & Borrowers' age & Number of years & $(+)$ & $\begin{array}{l}\text { Nguyen and Pham (2010); Truong and } \\
\text { Tran (2010) }\end{array}$ \\
\hline Gender & $\begin{array}{l}\text { Borrowers' } \\
\text { genders }\end{array}$ & $\begin{array}{l}\text { 1: Male } \\
0: \text { Female }\end{array}$ & $(+)$ & $\begin{array}{l}\text { Khandker (2005); Lam (2017); Chien } \\
\text { and DeVaney (2001), Nuryartono, Zeller } \\
\text { and Schwarze (2005) }\end{array}$ \\
\hline Assets & $\begin{array}{l}\text { The value of } \\
\text { collateral meeting } \\
\text { the banks' } \\
\text { requirements }\end{array}$ & In million & $(+)$ & $\begin{array}{l}\text { Le and Pham (2011); Nguyen and Pham } \\
\text { (2010); Zhu and De'Armond (2005). } \\
\text { Nguyen and Lien (2019) }\end{array}$ \\
\hline Incomes & $\begin{array}{l}\text { Borrowers' } \\
\text { incomes }\end{array}$ & In million & $(+)$ & $\begin{array}{l}\text { Barslund and Tarp (2008), Okurut and } \\
\text { Bategeka (2006); Mohamed (2003) }\end{array}$ \\
\hline Documents & Loan documents & $\begin{array}{l}\text { Complicated documents }=0 \\
\text { Simple documents }=1\end{array}$ & $(+)$ & $\begin{array}{l}\text { Chien and DeVaney (2001); Nguyen and } \\
\text { Nguyen (2011); Lai (2012) }\end{array}$ \\
\hline $\begin{array}{l}\text { Educational } \\
\text { levels }\end{array}$ & $\begin{array}{l}\text { Borrowers' } \\
\text { educational } \\
\text { levels }\end{array}$ & $\begin{array}{l}\text { Undergraduates }=0 \\
\text { Postgraduates }=1\end{array}$ & $(+)$ & $\begin{array}{l}\text { Nguyen and Pham (2010); Truong and } \\
\text { Tran (2010); Mohamed (2003); Kim and } \\
\text { DeVaney (2001) }\end{array}$ \\
\hline Jobs & Borrowers' jobs & $\begin{array}{l}\text { Unstable ones }=0 \\
\text { Stable ones }=1\end{array}$ & $(+)$ & $\begin{array}{l}\text { Hawley and Fujii. (1991); Nguyen and } \\
\text { Nguyen (2011); Lai (2012) }\end{array}$ \\
\hline Planning & $\begin{array}{l}\text { Borrowers' } \\
\text { business plans }\end{array}$ & $\begin{array}{l}\text { Having business plans }=1 \\
\text { Not having business plans }=0\end{array}$ & $(+)$ & $\begin{array}{l}\text { Chien and DeVaney (2001); Truong and } \\
\text { Tran (2010); Mohamed (2003) }\end{array}$ \\
\hline Experience & $\begin{array}{l}\text { Borrowers' } \\
\text { business } \\
\text { experience }\end{array}$ & $\begin{array}{l}\text { More than } 3 \text { years of } \\
\text { experience }=1 \\
\text { Less than } 3 \text { years of } \\
\text { experience }=0\end{array}$ & $(+)$ & $\begin{array}{l}\text { Zhu and De'Armond (2005); Nguyen } \\
\text { and Pham (2010); Truong and Tran } \\
\text { (2010). }\end{array}$ \\
\hline $\begin{array}{l}\text { Capability } \\
\text { of Individual } \\
\text { access to } \\
\text { Banks' credits }\end{array}$ & $\begin{array}{l}\text { Capability of } \\
\text { Individual access } \\
\text { to Banks' credits }\end{array}$ & $\begin{array}{c}Y=1 \text { Individual access } \\
\text { to Banks' credits, }=0 \\
\text { inaccessible Individual to } \\
\text { Banks' credits }\end{array}$ & $0 / 1$ & $\begin{array}{l}\text { Experts' surveys and summarizing the } \\
\text { profiles }\end{array}$ \\
\hline
\end{tabular}

Y: A binary variable with 02 values: $\mathrm{Y}=1$ is an individual who accesses bank credits, $\mathrm{Y}=0$ is an individual who does not have access to bank capital.

Table 1: A Summary of variables 


\section{Independent variables include:}

- The group of borrowers' variables relates to personal characteristics such as age, gender, and educational level. The variable of borrowers' resources such as total asset value and reputation is an easily convertible resource, so credit institutions should base lending decision on these and valid papers related to real estate assets.

- A direct survey of 300 individual borrowers including 150 people with access to credits and 150 people without accessing to credits at six commercial banks in Tra Vinh Province, Viet Nam - Bank of Agriculture and Rural Development, Bank for Foreign Trade Commercial Bank, Bank for Investment and Development of Vietnam, Asia Commercial Bank in Tra Vinh, Sai Gon Commercial Joint Stock Bank, and Bank of East Asia.

\section{Research Results}

In Table 2, it can be seen the Sig. of the variables with values $<0.05$, so the independent variables in the Binary Logistic regression model are correlated with the dependent variables and credit accessibility of individual consumers. The level of statistical significance of the regression coefficients has reliability level above $95 \%$, the sign of the regression coefficients is in line with expectations.

a) The job variable: $\mathrm{B}_{1}=1,581, \mathrm{P}_{0}=10 \%$ và $\mathrm{e}^{\mathrm{B} 1}=4,859$

b) In terms of the ability to access banking credits of $10 \%$, when other factors remain unchanged, the person with stable occupation increases by 1 unit, the probability of accessing banking credits will be $33.8 \%$ (increase by $23.8 \%$ of initial probability of $10 \%)$.

c) Educational level variable: $\mathrm{B} 2=1,307, \mathrm{P} 0=10 \%$ and $\mathrm{eB} 2=3,697$
In the aspect of the ability to access bank credit is $10 \%$, when other factors remain unchanged, the person has a level higher than 1 unit, the probability of accessing bank credit will be $29.1 \%$ (an increase of $19.1 \%$ of original probability of $10 \%$ ).

d) Asset variable: $\mathrm{B}_{3}=0,782, \mathrm{P}_{0}=10 \%$ and $\mathrm{e}^{\mathrm{B} 3}=2,187$

Access to banking credits is $10 \%$, when other factors remain unchanged, the person with assets increases by 1 unit, the probability of accessing bank credit will be $19.5 \%$ (up by $9.5 \%$ compared to the original probability of $10 \%$ ).

Income variable: $\mathrm{B} 4=0,505, \mathrm{P} 0=10 \%$ and $\mathrm{eB} 4=1,657$

The ability to access to banking credits is $10 \%$, when other factors remain unchanged, the customers' income increases by 1 unit, the probability of accessing Bank credit will be $15.5 \%$ (increase by $5.5 \% \%$ of original probability of $10 \%$ ).

Document variable: $\mathrm{B}_{5}=2,013, \mathrm{P}_{0}=10 \%$ and $\mathrm{e}^{\mathrm{B} 5}=7,483$

In terms of the $10 \%$ access to banking credits, when other factors remain the same, the customers' document is simpler than 1 unit, the probability of accessing banking credits will be $45.5 \%$ (an increase of $35,5 \%$ of the original probability of $10 \%)$.

Business plan variable: $\mathrm{B} 6=1,171, \mathrm{P} 0=10 \%$ and $\mathrm{eB} 6=3,226$

The ability to access to bank credit is $10 \%$, when other factors remain unchanged, if there is a business plan, the probability of customers' accessing banking credits will be $26.4 \%$ (up $16.4 \%$ compared to original probability of $10 \%$ ).

Experience variable: $\mathrm{B} 7=2,364, \mathrm{P} 0=10 \%$ and eB7 $=10,633$

The ability to access to bank credit is $10 \%$, when other factors remain unchanged, having more than 1 year experience, the probability of customers' accessing banking credits will be $54.2 \%$ (up $44.2 \%$ compared to the original probability of $10 \%$ ).

Table 2: Variables in the Equation

\begin{tabular}{|c|c|c|c|c|c|c|c|c|c|}
\hline & \multirow{2}{*}{ B } & \multirow{2}{*}{ S.E. } & \multirow{2}{*}{ Wald } & \multirow{2}{*}{ df } & \multirow{2}{*}{ Sig. } & \multirow{2}{*}{$\operatorname{Exp}(B)$} & \multicolumn{2}{|c|}{ 95\% C.I.for EXP(B) } \\
\hline & & & & & & & & Lower & Upper \\
\hline \multirow{8}{*}{$\begin{array}{l}\text { Step } \\
1^{a}\end{array}$} & Jobs & 1,581 & 0,538 & 8,631 & 1 & $0,003^{* * *}$ & 4,859 & 1,693 & 13,950 \\
\hline & $\begin{array}{l}\text { Educational } \\
\text { levels }\end{array}$ & 1,307 & 0,615 & 4,525 & 1 & $0,033^{* *}$ & 3,697 & 1,108 & 12,329 \\
\hline & Assets & 0,782 & 0,284 & 7,588 & 1 & $0,006^{\star * *}$ & 2,187 & 1,253 & 3,816 \\
\hline & Incomes & 0,505 & 0,206 & 6,012 & 1 & $0,014^{* *}$ & 1,657 & 1,107 & 2,482 \\
\hline & Documents & 2,013 & 0,459 & 19,188 & 1 & $0,000^{* * *}$ & 7,483 & 3,041 & 18,414 \\
\hline & Planning & 1,171 & 0,544 & 4,637 & 1 & $0,031^{\text {** }}$ & 3,226 & 1,111 & 9,370 \\
\hline & Experience & 2,364 & 0,386 & 37,496 & 1 & $0,000^{* * *}$ & 10,633 & 4,989 & 22,659 \\
\hline & Constant & $(11,368)$ & 1,519 & 55,976 & 1 & 0,000 & 0,000 & & \\
\hline
\end{tabular}




\section{Policy Implications}

\section{Focusing on collaterals of individual borrowers:}

The research confirmed that the collaterals are one of the necessary conditions for the banks to approve loans to individual customers. The collaterals should consist of land, houses, valuable documents (savings book, certificate of deposit), means of transport, and so on. Therefore, collaterals that support individual customers are not only easy to access credits, but they also earn lower interest rates than unsecured loans because the lending rates of banks always include quantified risks. Credit institutions always prioritize customers with collaterals and lend them more capital than customers without collaterals. However, the banks should not consider the roles of the collaterals as the only factor in lending decisions. The collaterals should only be considered as the second source of debt collection behind the cash flow generated from the business plan. When handling collaterals, it always takes a lot of time, procedures and costs.

\section{Improving the transparency in proving the income of individual customers:}

Those who can demonstrate a stable source of incomes are more likely to access credits than those with precarious incomes. Those customers earn too low income to support their lives, and it is also difficult for commercial banks to approve loans for capitals. In terms of effective calculation, in the immediate future, commercial banks cannot consider their repayment capacity, not to mention that, for many other reasons, they can use part of their newly-borrowed capital to spend. The misuse of this loan obviously leads to a dead end.

\section{Focusing on leaning loan documents:}

The documents and method of loan can greatly affect the access of individual customers. Credit institutions that have simple procedures and simple lending methods will attract many customers. Most individual customers now borrow directly, nearly $82 \%$ of the 150 people who do not have access to bank credits state that this is due to complicated and difficult loan documents. The banks cannot set their own loan documents, but must follow the law. In litigation before the courts, the staff of the banks can hardly win if they do not ensure the loan documents and records.

\section{Customers' effective business plans:}

It can be vital for customers to use capital for the right purposes, and expenditures must be strictly and seriously managed, not to use loans for wrong purposes, causing shortages of capital for businesses, reducing incomes and sources of debt repayment to banks. The survey statistics show that $87.33 \%$ of individuals do not have access to bank credits because they do not have business plans, and nearly
$68 \%$ of individuals with good business plans have access to capital.

\section{Improving the qualifications and experience of the customers:}

Survey statistics showed that $62 \%$ of people who access to bank credits have more than five years of experience. The more working experience people have accumulated, the less risks they have in businesses and the more likely they can access banking credits. Customers should actively participate in technical training courses, short-term start-up courses, or effective business models from the province's counseling and supporting programs.

\section{Supervising individual customers using loans for the right purposes:}

It should be compulsory to ensure the borrowers use capital for the right purposes, and expenditures must be strictly and seriously managed to avoid using loans for wrong purposes, causing shortages of capital for business, and reducing incomes and sources of debt repayment to banks. Statistics showed that $87.33 \%$ of individuals do not have access to bank credit because of an absence of business plan, whereas nearly $68 \%$ of individuals with good business plan have access to capital.

\section{Promoting borrowers'business experience when borrowing from the banks:}

The survey showed that $62 \%$ of people who have access to bank credit have more than five years of experience, and the more working experience they accumulate, the less risks they have in business, and the more likely they can access bank credits. Customers should actively participate in technical training courses, short-term start-up courses, or effective business models from the province's counseling and support programs.

\section{References}

Barslund, M., \& Tarp, F. (2008). Formal and Informal Rural Credit in Four Provinces of Vietnam; Journal of Development Studies, 44(4), 485-503. DOI: 10.1080/00220380801980798.

Chien, Y. W., \& DeVaney, S. (2001). The Effects of Credit Attitude and Socioeconomic Factors on Credit Card and Installment Debt. The Journal of Consumer Affairs, 35(1), 162-179. DOI: 10.1111/j.1745-6606.2001.tb00107.x

Hawley, C., \& Fujii, K. (1991). Discrimination in consumer credit markets. Eastern Economic Journal, 17(1), 13-17.

Kim, H., \& DeVaney, S. (2001). The Determinants of Outstanding Balances Among Credit Card Revolvers. Financial Counseling and Planning, 12, 10-12. 
Lai, T. T. H. (2012). Factors affecting access to credit capital of farmers in Ben Cat district, Binh Duong province. Master's thesis in Economics, Ho Chi Minh Open University.

Lam, S. N. (2017). Factors affecting the official access to credit of households in Rach Gia city, Kien Giang province. Master's Thesis in Economics, University of Economics Ho Chi Minh.

Le, H. B. H. (2019). Improving the quality of loans to individual customers at Agribank Ngoc Lac - Thanh Hoa province. Review of Finance, Retrieved January 15, 2019 from: http:// tapchitaichinh.vn/tai-chinh-kinh-doanh/nang-cao-chat-luongcho-vay-khach-hang-ca-nhan-tai-agribank-ngoc-lac-thanhhoa-302242.html.

Le, K. N., \& Pham, V. H. (2011). Factors determining the amount of official credit loans of farm households in Hau Giang province, Viet Nam. Banking Review, 9, 42-48.

Mohamed, K. (2003). Access to formal and quasi-formal credit by small holder farmers and artisanal fishermen: a case of Zanzibar. Mkuki na Nyota Publishers, 21-24.

Nguyen, H. H., \& Lien, T. T. (2019). Factors Influencing Family Business Decision for Borrowing Credit from Commercial Banks: Evidence in Tra Vinh Province, Viet Nam. Journal of Asian Finance, Economics and Business, 6(2), 119-122. https:// doi.org/10.13106/jafeb.2019.vol6.no2.119

Nguyen, P. L., \& Nguyen, M. D. (2011). The ability to access formal credit of farmers in suburban Hanoi, the case in Hoang Van Thu commune, Chuong My district. Journal of Science and Development, 9(5), 844-852.

Nguyen, Q. O., \& Pham, T. M. D. (2010). Factors affecting access to formal credit by farmers in suburban Ha Noi, Viet Nam. Journal of Science and Development, 9(5), 844-852.

Nguyen, T. H. Y. (2019). Finalizing credit appraisal at stateowned commercial banks in Ha Giang province, Viet Nam. Review of Finance, Retrieved February 15, 2019 from: http:// tapchitaichinh.vn/ngan-hang/ thien-thien-tham-dinh-dung- dung-tai-ngan-commodity-mai-co-phan-nha-nuoc-o-hagiang-302125.html.

Nuryartono, N., Zeller, M., \& Schwarze, S. (2005). Credit Rationing of Farm Households and Agricultural production: Empirical Evidence in the Rural Areas of Central Sulawesi, Indonesia. Conference on International Agricultural Research for Development, Stuttgart-Hohenheim, 11-13.

Okurut, F. N., \& Bategeka, L. (2006). The Impact of Microfinance on the Welfare of the Poor in Uganda. Journal of Social and Economic Policy, 3(1), 59-74.

Shahidur. R. K. (2005). Microfinance and Poverty: Evidence Using Panel Data from Bangladesh. The World Bank Economic Review, 19(2), 263-286.

State Bank Tra Vinh Branch. (2018). Summary report on Banking activities in Tra Vinh province. State Bank of Viet Nam.

Tran, A. K., \& Thai, T. T. (2013). Factors affecting consumer credit access in commercial banks of households in Can Tho City, Viet Nam. Can Tho University Journal of Science, 28, 26-32.

Tran. T. T. (2020). The Impact of Balanced Scorecard on Performance: The case of Vietnamese Commercial Banks. Journal of Asian Finance, Economics and Business, 7(1), 71-79. https://doi.org/10.13106/jafeb.2020.vol7.no1.71

Truong, D. L., \& Tran, B. D. (2010). Factors affecting the access to formal credit of farm households in Kien Giang province, Viet Nam. Banking Review, 4, 29-32.

Van. D. H. (2020). The Impacts of Empowerment on the Teamwork Performance: Evidence from Commercial Banks in Vietnam. Journal of Asian Finance, Economics and Business, 7(4), 267273. https://doi.org/10.13106/jafeb.2020.vol7.no4.267.

Zhu, D., \& De'Armond, D. (2005). The Factors of Consumer Debt: A look at demographic, economic, and credit management variables among participants of the Consumer Expenditure Survey. Presented at Association for Financial Counseling and Planning Education, Scottsdale, Arizona. 